\title{
Public Health and the Aging Population
}

NATHAN W. SHOCK, Ph.D.

A FEW FACTS from the report of the 1961 White House Conference on Aging (1) emphasize the magnitude of the aging problem in the United States:

We have 16 million people over age 65 today.

There will be 32 million over 65 in the next 40 years.

This aged population is expected to represent 1 out of every 10 persons.

While the health of many of these older people will be good, there will also be many whose health will be so impaired that they will require various services. The older we get, the more liable we are to health impairment and the more we need hospital, medical, nursing, restorative, and other services. For example, people over 65 spend $21 / 2$ times as many days in hospitals as those under 65. They account for about 18 percent of the admissions to general hospitals and comprise almost one-third of the hospitalized population ( $\mathscr{Z})$.

In a sense, the problems of our older people, particularly their health problems, have come about because we have for many years focused our principal endeavors on children and people in the earlier years of life. The result is that the children and young adults whose lives have been saved now swell the middle-age and oldage population.

In 1900 the average life expectancy at birth was only about 46 years for white males and about 48 years for white females in the United States. In 1961 the life expectancy for males is

Dr. Shock is chief, Gerontology Branch, National Heart Institute, Public Health Service, Baltimore City Hospitals, Baltimore, Md. This paper is based on an address to the 32d Annual Convention of the Georgia Public Health Association, Savannah, Ga., May 23, 1961. about 67 years and for females it is almost 73 years (3). Most of this difference is due to the marked reduction in infant mortality and mortality from the diseases of childhood and early adulthood brought about by research discoveries and effective health programs.

Improved methods of treatment have had some effect on mortality at the upper ages as well. In 1850, the person who had survived the hazards of infancy and escaped the infectious diseases of childhood and the fatal diseases of middle age so that he attained the age of 60 had a 50-50 chance of living an additional 16 years. Today the 60-year-old has an expectancy of 20 years of additional life.

When new medical discoveries are widely applied, significant changes in death rates occur. Thus, before the discovery of insulin in 1922, the average life expectancy of the 30-year-old diabetic was only 4-6 years. With the introduction of procedures for early detection of diabetes and the use of insulin therapy, the life expectancy of the 30-year-old diabetic has increased to 35 years, or to a total life expectancy of 65 years. During the early part of this century, pneumonia was often a fatal disease among the elderly with death rates ranging from 700 to 1,000 per 100,000 population over age 60 . The introduction of sulfa drugs and antibiotics has reduced mortality rates from pneumonia and influenza to less than 100 per 100,000 population over age 60 . Medical advances in the prevention and care of cardiovascular disease and cancer may produce even further increments in the population over age 60 in the future (3).

But we are only now beginning to cope with the problems of old people through a vigorous attack not only in research but also in community services. 


\section{Search for Basic Knowledge}

As early as 1941, the National Institutes of Health of the Public Health Service recognized that aging and the chronic diseases would become of increasing importance in public health. To provide basic knowledge about aging, the Section on Gerontology was established in collaboration with the Baltimore City Hospitals. It is now the Gerontology Branch of the National Heart Institute.

The primary goal of the Gerontology Branch has been to describe age changes in individuals who have been carefully screened to exclude those with diagnosable diseases in order to set baselines against which the effects of disease and therapeutic regimens can be measured. Since aging is a process which takes place throughout the entire adult lifespan, all tests have been applied to individuals between the ages of 20 and 95 years. These tests are designed to measure the functional capacities of a wide range of physiological systems, such as cardiovascular, pulmonary, neuromuscular, and renal, as well as overall responses, such as recovery from standardized exercise and metabolic responses to specific stimuli.

In studies completed so far tests have been made on different individuals at each decade, that is, by the cross sectional method. To define age changes accurately, repeated observations must be made on the same individual as he ages. Such a longitudinal study is now in progress at the Gerontology Branch using more than 400 men aged $20-100$ years who are leading active lives in the community. Each subject volunteers 2 days for testing procedures at the Baltimore City Hospital every 18 months.

From the cross sectional studies we can make a number of generalizations that have significance for health maintenance (4). Perhaps our most striking finding is that many of the beliefs about older people are not true. Not all physiological characteristics show decrements with age. When the body is at rest, characteristics of the blood, which determine the environment in which the cells of the body exist, are closely regulated even into advanced ages. Thus, resting blood volume (5), acidity of the blood (6), its osmotic pressure, and its sugar content ( 7$)$ are not systematically altered by advancing age. However, when extra demands are placed on the individual, either by environmental factors or by experimental conditions, older individuals require more time to reestablish equilibriun than do the young. Although the resting level of blood sugar is the same in old and young, the old are slower in removing excess sugar from the blood than are the young (8). After standardized exercise, the old require more time for recovery with respect to pulse rate, breathing, or rate of oxygen uptake than do the young (9). Normal elderly people are able to make the adjustments to stress and displacing stimuli, but they require more time than do the young. From these and many similar experiments, we conclude that aging is associated with a gradual reduction in reserve capacities.

Where decrements in the performance of individuals or of specific organ systems occur, the changes are gradual throughout the lifespan. Thus the resting cardiac output falls by 50 percent between the ages of 20 and 95 years (10). In other characteristics, such as the speed of conduction of nerve impulse, the fall is only 15 percent over the same age span (11). Examination of a wide variety of functional tests shows that aging takes place at different rates among different organ systems. The greatest decrements occur in functions that require coordination and integration among a number of different organ systems such as physical exercise. Thus aging is also accompanied by a breakdown of integrative mechanisms (12).

Research has also shown us the wide individual differences in the effects of age on any performance. For example, we have found that some individuals at the age of 90 have kidney functions as good as the average values for 40 year-olds (13). We must therefore recognize that chronological age in itself is a poor index of capacity and that each individual requires special study and assessment to determine both his strengths and limitations.

Since one of the primary characteristics of aging is the gradual loss of reserve capacities, it is essential that we find out how this comes about. Both histological and physiological studies show that a part of this loss is due to the gradual dropping out of functioning cells and units from key tissues, where replacement no 
longer occurs in the adult (14). For example, the reduction in kidney function with age is due in part to the loss of nephrons from the kidney (13). The gradual reduction in basal metabolism with age is due to a reduction in the total amount of functioning tissue (15). Maintenance of functioning in advanced ages will therefore depend on developing methods for preventing tissue losses, and these measures must be introduced early in life.

Although loss of functioning cells plays an important role in aging, changes in intracellular enzymes also occur. The activity of some enzymes associated with energy transformations in cells shows small but significant decrements with increasing age $\left(16,1^{7}\right)$. Whether or not these changes are reversible is not yet known.

Advancing age is accompanied by psychological as well as biological changes (18-21). In addition to an increasing incidence of sensory impairments, older people undergo a slowing of responses. Reaction time lengthens, and performance diminishes in tests in which time is a factor. There is little evidence, however, that intellectual capacity diminishes until advanced old age is reached. Activities tend to be more sedentary, and memory for recent events is less effective in the old than in the young. Older people retain their capacity to learn, but they may require more time and motivation becomes increasingly important. Skills used continuously throughout life show very little impairment with increasing age, a fact which leads to the presumption that disuse may play a primary role in the impairment of some performances with advancing age.

\section{Socioeconomic Characteristics}

Adult behavior is also influenced by the demands and norms set by our culture. The young adult is expected to engage in activities that result in the establishment of an independent family unit of his own, whereas similar behavior in the elderly is regarded as inappropriate. One of the primary problems of the aged lies in the fact that our society has not yet clearly defined the role of the elderly. Public health officers should assume leadership in establishing the aged as active participants in the whole life of the community.
During the past 10 years, other investigators have added greatly to our knowledge about older people as a group. We know that they are likely to live in older, less adequate houses and that they have lower incomes than the rest of the population (2Q). Less than one-third of males over age 65 are employed, but the income of the employed group is substantially greater than that of the retired group (23). It is also the employed elderly who participate in health insurance plans. Their need for medical and hospital care is substantially greater than that of the rest of the population. Almost 50 percent of those over age 65 receive incomes from the Federal old age and survivors insurance program. In March 1959, the average monthly payment was $\$ 72$ and about one-half of all married couples were receiving less than $\$ 125$ per month (24). Comparing these incomes with the Bureau of Labor Statistics estimate that a retired couple needs $\$ 1,900$ per year to maintain an adequate level of living, it is clear that most retired couples dependent on Federal old age and survivors insurance payments must exist on marginal incomes.

Sociologists have characterized the aged as a quasi-minority group in our present culture, because they are excluded from participating fully in our society and are dominated by other groups who set the norms or standards of behavior for them (24). Older workers are often the last to be hired and the first to be fired. Compulsory retirement excludes individuals from employment after a certain age without consideration for the capabilities of the individual. Clearly, many of the problems confronting older people are manmade.

\section{Health Department Action}

The 1961 White House Conference on Aging outlined in detail many of these problems, and, in its recommendations, offered a blueprint for action. Public health has a key role in this effort, and local public health officers represent the primary source of action.

In meeting the challenge of the aging of our population I believe a major task of the health department is education. It is up to the health department to see that knowledge gained through research is translated into action. 
Much that has been learned about treatment and rehabilitation among the aged is not yet being applied. An aggressive, optimistic approach in which all the knowledge and methods now available are put to use must replace attitudes of fatalism toward diseases of the elderly.

The health department can also help to educate the aging individual himself not only to accept certain limitations which age may bring but also to recognize the individuality of aging and the fact that many activities may be preserved. In this connection, programs for health maintenance can make a major contribution.

In addition, much can be done in educating the community to use the many talents remaining to the elderly. With a minimum of training, many aged people could make friendly visits to less capable elderly persons and also could perform homemaking services for such persons. Instead of being excluded from the mainstream of community activities, older people should be included to the fullest extent of their capabilities.

In collaboration with private agencies, the health department should also work toward the coordination of services for older people. Coordinated medical care which permits easy movement of patients from the home to the hospital, to the nursing home, and back to the home must be developed. Home care and such ancillary services as visiting nurses, home maker services, "meals on wheels," and activity centers for the aged also need to be developed and coordinated.

As in the past community health services have been expanded and adapted to meet whatever challenges arose, so today they must be geared to help meet the needs of our mushrooming population of old people.

Research has not yet discovered ways of preventing many of the diseases that afflict elderly people. However, we do know that it is often unnecessary to use precious hospital beds for long-term convalescence. We also know that rehabilitation methods can increase the capacities for self-care in many elderly patients who in the past have been abandoned to a life of expensive custodial care. Rehabilitation means more than restoring capability for employment; it also means preparing individuals for self- care. With increasing age, the probability of illness, with hospitalization, increases. It is high time we consider plans whereby individuals may begin early in life to insure themselves against catastrophic medical needs later on.

The current heart program in Georgia is an excellent example of how public and private agencies can work with the physicians and the individual. Georgia's first heart clinic, some 10 or 12 years ago, was, I understand, a cooperative enterprise of the heart association, the health department, Emory University, and private physicians. Not only has the program of services to people grown through this cooperative approach, but postgraduate education for physicians and paramedical personnel has been built into the program. In conjunction with this established cooperative structure, a program of rehabilitative and other services to stroke victims has been developed.

\section{Hope for Future Progress}

The best hope of the greatest future progress in solving the problems of the aged lies in gerontological research in biological, medical, social, psychological, and other fields. This research cannot be done solely in the laboratory with the test tube or experimental animal. Gerontological research must also have the community and the population for its laboratory. Studies of cells are, of course, extremely valuable for a better understanding of the aging process, but studies of people, among people and in the places where they live, will perhaps be equally as important, or even more important. Solutions to the problems public health faces in its efforts to help the aging will come, in a great many instances, from studies in which the laboratory is, in effect, the community. Research is not an island; it is part of the main continent of human activity, and it is dependent upon working with people to achieve its goals.

\section{REFERENCES}

(1) U.S. Department of Health, Education, and Welfare: The nation and its older people. Report of the White House Conference on Aging, Washington, D.C., January 9-12, 1961. U.S. 
Government Printing Office, Washington, D.C., 1961.

(2) Fraenkel, M.: Hospital data in community planning for the aged. Paper presented at meeting of the American Association for the Advancement of Science, New York, Dec. 29, 1960.

(3) Shock, N. W.: Trends in gerontology. Ed. 2. Stanford University Press, Stanford, Calif., 1957.

(4) Shock, N. W.: Some of the facts of aging. In Aging: some social and biological aspects, edited by N. W. Shock. Publication No. 65. American Association for the Advancement of Science, Washington, D.C., 1960, pp. 241-260.

(5) Cohn, J. E., and Shock, N. W.: Blood volume studies in middle-aged and elderly males. Am. J. M. Sc. 217 : 388-391 (1949).

(6) Shock, N. W., and Yiengst, M. J.: Age changes in acid-base equilibrium of blood of males. J. Gerontol. 5 : 1-4 (1950).

(7) Smith, L. E., and Shock, N. W.: Intravenous glucose tolerance tests in aged males. J. Gerontol. 4 : 27-33 (1949).

(8) Silverstone, F. A., Brandfonbrener, M., Shock, N. W., and Yiengst, M. J.: Age differences in intravenous glucose tolerance tests and response to insulin. J. Clin. Invest. $36:$ 504-514 (1957).

(9) Norris, A. H., Shock, N. W., and Yiengst, M. J.: Age changes in heart rate and blood pressure responses to tilting and standardized exercise. Circulation 8: 521-526 (1953).

(10) Brandfonbrener, M., Landowne, M., and Shock, N. W.: Changes in cardiac output with age. Circulation 12: 557-566 (1955).

(11) Norris, A. H., Shock, N. W., and Wagman, I. H. : Age changes in maximum conduction velocity of motor fibers of human ulnar nerves. J. Appl. Physiol. 5: 589-593 (1953).

(12) Shock, N. W.: Current concepts of the aging process. J.A.M.A. 175: 654-656 (1961).
(13) Shock, N. W.: Age changes in renal function. In Cowdry's problems of aging, edited by $\mathbf{A}$. I. Lansing. Ed. 3. Williams \& Wilkins Co., Baltimore, 1952, pp. 614-630.

(14) Andrew, W., Shock, N. W., Barrows, C. H., Jr., and Yiengst, M. J.: Correlation of age changes in histological and chemical characteristics in some tissues of the rat. J. Gerontol. 14: 405-414 (1959).

(15) Shock, N. W.: Metabolism and age. J. Chronic Dis. 2 : 687-703 (1955).

(16) Barrows, C. H., Jr., Yiengst, M. J., and Shock, N. W.: Senescence and metabolism of various tissues of rats. J. Gerontol. 13: 351-355 (1958).

(17) Barrows, C. H., Jr., Falzone, J. A., Jr., and Shock, N. W. : Age differences in the succinoxidase activity of homogenates and mitochondria from the livers and kidneys of rats. $J$. Gerontol. 15 : 130-133 (1960).

(18) Shock, N. W., Gerontology (later maturity). In Annual review of psychology, edited by C. $P$. Stone and D. W. Taylor. Annual Reviews, Inc., Stanford, Calif., 1951, pp. 353-370.

(19) Lorge, I.: Gerontology (later maturity). Ann. Rev. Psychol. 7 : 349-364 (1956).

(20) Birren, J. E.: Psychological aspects of aging. Ann. Rev. Psychol. 11: 161-198 (1960).

(21) Birren, J. E., editor : Handbook of aging and the individual. University of Chicago Press, Chicago, 1959.

(22) Donahue, W., editor: Housing the aging. University of Michigan Press, Ann Arbor, 1954.

(23) Tibbitts, C., editor: Handbook of social gerontology. University of Chicago Press, Chicago, 1960.

(24) Barron, M. L.: The aging American: an introduction to social gerontology and geriatrics. Thomas Y. Crowell Co., New York, 1961.

\section{Housing for the Elderly}

The Federal Housing and Home Finance Agency has a new Office of Housing for the Elderly which will coordinate the agency's various programs for housing older persons. The programs include the many mortgage insurance plans of the Federal Housing Administration, the Federal National Mortgage Association program for purchasing FHA-insured mortgages covering multifamily units for older persons, the direct Federal loan plans authorized by the Housing Acts of 1959 and 1961, and public housing projects.

The central office will work out standard policies and rules with the constituent agencies, provide information and counseling services concerning the various programs, conduct research, and assist in training personnel. The central office itself will not administer any of the program operations. 


\section{Translated Readings}

The following items have been culled from the CIA Scientific Information Reports, distributed by the Office of Technical Services, U.S. Department of Commerce. Numbers following each item refer to the issue and item, in that order. All issues are from the PB $131891 \mathrm{~T}$ series.

\section{Sundew Antibiotic}

Plumbagin, an antibiotic, 2-methyl-5-oxynaphthoquinone-1,4, is the factor in a roundleaf grass called sundew, according to B. P. Koslov $(55,114)$. It was found effective against pertussis and tuberculosis. The bibliography has 25 titles.

\section{Fatigue Measurement}

Methods of measuring occupational fatigue are discussed by Prof. S. A. Kosilov, in Vestnik Akademii meditsinkikh nauk S.S.S.R. (55, 139).

\section{Mental Health}

Current and prospective improvements in psychiatric services in the U.S.S.R. are described by Z. N. Serebryakova in the Zhurnal nevropatologii $i$ psikhiatrii imeni S.S. Korsakov $(55,146)$.

\section{Manpower}

The training of physicians in sanitary specialties in the Soviet Union uses facilities of a special institute in Leningrad and teachers of "sanitary hygiene" at 22 other medical institutes. More than 14,000 students are enrolled in these sanitary courses.

With 25,300 physicians employed in epidemic control by the U.S.S.R. Ministry of Health, annual admission of 1,600 new students of hygiene is expected to swell the total number of sanitary physicians to 36,000 in 1965 .

The interest in training in preventive medicine was accented by a decree of the Central Committee of the Communist Party of the Soviet Union and the Council of Ministers, U.S.S.R., January 14, 1960. The program out- lined in an unsigned article in Sovetskoye zdravookhraneniye indicates that "sanitary-epidemiological stations must become fundamental components of sanitary hygiene faculties . . . strengthening the bond between education and life through the extensive participation of students in socially useful work" $(56,129)$.

\section{Brucellosis Vaccine}

A report on vaccination of 2,750 persons vaccinated cutaneously with a preparation from Brucella abortus strain 19-BA is published in the Zhurnal mikrobiologii, epidemioligii, $i$ immunobiologii by I. F. Taran $(5 \%, 105)$.

\section{Noise Effects}

Physiological effects of noise of low frequency and high intensity were observed in a population of young workers by A. A. Arkad' yevskiy. His results, reported in Gigiyena $i$ sanitariya, indicate a considerable disturbance of functions by intensities of 100 decibels with extended delay of recovery $\left(5^{17}, 12^{n}\right)$.

\section{Radiation}

A collection of reports on the chemical protection of organisms from ionizing radiations, edited by V. A. Balabukha, was published in 1960 in Moscow $(5 \%, 135)$. The second part deals with elimination of radioactive elements from the body.

\section{Noise Measurement}

The quality of devices and methods used in measuring noise in the Soviet Union, the United States, and in Western Europe is reviewed by I. A. Gradskiy in Gigiyena $i$ sanitariya (58, $116 a)$.

\section{Foot-and-Mouth Disease}

High immunogenic properties, with a duration of 2-5 months for a foot-and-mouth disease vaccine made from rabbit-adapted virus are reported by S. R. Didovets, chief, veterinary administration, Kiev. The recommended method is a dose of $1 \mathrm{ml}$. of the vaccine in the tunica submucosa of the upper jaw $(50,10 \%)$. 